\title{
Effect of Acute Hypoxia on Blood Pressure and Electroencephalogram of Newborn Babies
}

\author{
N. R. C. ROBERTON` \\ From the Nuffield Neonatal Research Unit, Hammersmith Hospital, London
}

Our current practice in the management of respiratory problems in the newborn baby, including those born prematurely, is directed towards maintaining arterial $\mathrm{Po}_{2}$ within the normal range for the immediate neonatal period $(60-90 \mathrm{~mm} . \mathrm{Hg})$, even if high environmental oxygen concentrations are required (Roberton et al., 1968). By this means it is hoped to prevent the increased mortality associated with restricted oxygen usage (Avery and Oppenheimer, 1960) and possibly to limit the incidence and severity of brain damage in survivors (McDonald, 1963; 1967).

The evidence relating arterial hypoxaemia to subsequent neurological deficit is, however, tenuous. There are no studies of neurological deficit in relation to blood gas tensions in newborn babies, and in McDonald's retrospective study of neonatal oxygen therapy and cerebral motor defect it is only in the babies of less than 31 weeks' gestation who had apnoeic attacks that the incidence of cerebral diplegia was inversely related to the length of oxygen therapy.

It is known that babies suffering from the respiratory distress syndrome (RDS) have a lower blood pressure than normal babies of the same weight (Neligan and Smith, 1960). Recent work on both animals and man (Adams et al., 1966; Brierly and Excell, 1966) has suggested that hypotension, particularly of sudden onset, may be an important factor in the causation of certain types of brain damage.

The neurological responses of newborn babies are largely controlled at a subcortical level, and cortical function is not easily tested except perhaps by the visual responses (Robinson, 1966). The responses of adults with cerebral cortical hypoxia who show dizziness and confusion (Moyer and Morris, 1954) cannot therefore be detected in babies. The EEG is known to be a sensitive indicator of cerebral hypoxia in both adult man and animals

Received April 29, 1969.

^In receipt of the Percy J. Neate Fellowship of the Clothworkers' Company. Present address: c/o Nuffield Institute of Medical Research, Oxford.
(Cahn et al., 1961; Gastaut, Fischgold, and Meyer, 1961). The EEG of the healthy full-term and premature baby has been extensively studied, and criteria of normality, though less well defined than in older children or adults, have been established (Dreyfus-Brisac, 1964; Goldie and Van Velzer, 1965). It, therefore, seemed justifiable to examine it as a possible index of cerebral cortical hypoxaemia in the newborn.

To investigate the relative importance of hypotension and hypoxaemia in causing changes in the EEG, simultaneous recordings of $\mathrm{P}_{2} \mathrm{O}_{2}$, systemic blood pressure, and EEG were made in newborn babies suffering from the respiratory distress syndrome or recurrent apnoea of prematurity.

\section{Material and Methods}

The babies studied were all being artificially ventilated with a positive pressure ventilator (Grausz, Watt, and Becket, 1967) via a naso-endotracheal tube, and at the time of the study were maintaining satisfactory blood gas tensions. Artificial ventilation of newborn babies may be followed by chronic lung disease (Northway, Rosan, and Porter, 1967), and we have encountered considerable problems with retained secretions, in addition to pulmonary infection, tracheal ulceration, and occasionally stenosis. Because of these problems we make frequent attempts to wean these babies off the respirator once satisfactory blood gas tensions are being maintained. These studies were made before and after switching off the respirator in such babies. The endotracheal tube was left in situ and $100 \% \mathrm{O}_{2}$ administered through it. When disconnected from the respirator, the babies were often apnoeic for up to one minute before they started spontaneous respirations. These were sometimes gasping in nature, though they were often regular and shallow but presumably inadequate, as EEG and $\mathrm{P}_{\mathrm{a}} \mathrm{O}_{2}$ changes occurred. EEG, ECG, and blood pressure measurements were recorded during the procedure, which was regarded as having failed if the EEG became significantly slower or flattened, or if there was obvious clinical deterioration. Arterial blood gas measurements were taken just before the respirator was switched off and again just before the respirator was restarted in cases where 'weaning' had failed. 


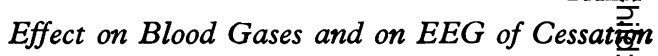

\begin{tabular}{|c|c|c|c|c|c|c|}
\hline \multirow{2}{*}{$\begin{array}{l}\text { Case } \\
\text { No. }\end{array}$} & \multirow{2}{*}{ Indication for Respirator Treatment } & \multirow{2}{*}{$\begin{array}{l}\text { Age When } \\
\text { Respirator } \\
\text { Cessation } \\
\text { Attempted (hr.) }\end{array}$} & \multicolumn{2}{|c|}{$\mathrm{P}_{\mathrm{a}} \mathrm{O}_{2}(\mathrm{~mm} . \mathrm{Hg})$} & \multicolumn{2}{|c|}{$p \mathrm{H}$} \\
\hline & & & Before & After & Before & After \\
\hline 1 & Apnoeic attacks & $26 \frac{1}{2}$ & 63 & 12 & - & - \\
\hline 2 & Apnoeic on admission (1) & $\begin{array}{r}76 \\
218\end{array}$ & $\begin{array}{r}140 \\
75\end{array}$ & $\begin{array}{l}11 \\
18\end{array}$ & $\underline{7 \cdot 51}$ & $\begin{array}{c}7 \cdot 33 \\
-\end{array}$ \\
\hline 3 & Apnoeic on admission & 6 & 35 & 10 & $7 \cdot 29$ & $7 \cdot 29$ \\
\hline 4 & Respiratory failure; ${ }^{\star}$ ? septicaemia & 33 & 106 & 39 & $7 \cdot 57$ & $7 \cdot 28$ \\
\hline 5 & $\begin{array}{r}\text { Apnoeic attacks (1) } \\
(2)\end{array}$ & $\begin{array}{l}32 \frac{1}{2} \\
34\end{array}$ & $\begin{array}{l}160 \\
140\end{array}$ & $\begin{array}{l}27 \\
32\end{array}$ & $\begin{array}{l}7 \cdot 40 \\
7 \cdot 40\end{array}$ & $\begin{array}{l}7 \cdot 22 \\
7 \cdot 30\end{array}$ \\
\hline 6 & Respiratory failure ${ }^{\star}(1)$ & $\begin{array}{l}97 \frac{1}{2} \\
98\end{array}$ & $\begin{array}{l}135 \\
230\end{array}$ & $\begin{array}{l}27 \\
26\end{array}$ & $\begin{array}{l}7 \cdot 67 \\
7 \cdot 69\end{array}$ & $\begin{array}{l}7 \cdot 39 \\
7 \cdot 38\end{array}$ \\
\hline 7 & $\begin{array}{r}\text { Apnoeic attacks (1) } \\
(2)\end{array}$ & $\begin{array}{r}8 \\
22\end{array}$ & $\begin{array}{l}65 \\
58\end{array}$ & $\begin{array}{l}12 \\
27\end{array}$ & - & - \\
\hline 8 & Apnoeic on admission (1) & $\begin{array}{l}10 \frac{1}{2} \\
15\end{array}$ & $\begin{array}{l}68 \\
51\end{array}$ & $\begin{array}{l}15 \\
12\end{array}$ & $\begin{array}{l}7 \cdot 40 \\
7 \cdot 28\end{array}$ & $\begin{array}{l}7 \cdot 28 \\
7 \cdot 28\end{array}$ \\
\hline 9 & Apnoeic attacks & 102 & 60 & 16 & $7 \cdot 36$ & $7 \cdot 34$ \\
\hline
\end{tabular}

* Respiratory failure-assessed by progressive acidemia and hypercapnia. IVH, Intraventricular haemorrhage.

A 12-channel EEG was recorded from the positions described previously (Goldie and Van Velzer, 1965). Small electrodes were either stuck into the scalp with collodion, or in some cases needle electrodes were used. The ECG was recorded simultaneously on the EEG tracing. For comparison between EEG activity at various periods during the recordings, the percentage activity exceeding $20 \mu \mathrm{V}$ in any 60 -second period was noted. Provided that activity exceeding $20 \mu \mathrm{V}$ was present in at least one channel, the EEG was regarded as active. In fact, in no case was there gross asymmetry of the record or purely focal activity. Flattening of the EEG was defined as the absence of any activity exceeding $10 \mu \mathrm{V}$. Percentage activity was noted for control tracings taken before the respirator was switched off and for each minute during the time the baby was not being artificially ventilated.

$\mathrm{P}_{\mathrm{a}} \mathrm{O}_{2}, p \mathrm{H}$, and $\mathrm{P}_{\mathrm{a}} \mathrm{CO}_{2}$ were measured on blood drawn from an umbilical arterial catheter lying within the abdominal aorta. The blood gases were measured immediately on a I.L. $p \mathrm{H} /$ blood gas analyser which requires only $0.1 \mathrm{ml}$. blood for all these estimations, and appropriate corrections were made for the baby's body temperature and for the errors due to calibrating the apparatus with gas mixtures instead of blood tonometered with gas mixtures (Roberton et al., 1968).

Blood pressure was recorded directly from the umbilical arterial catheter connected to a pressure transducer which wrote out the blood pressure directly on a Mingograph recorder.
Throughout the investigation the baby remained within the incubator in its own cubicle. The incubator was usually switched off during the recording because of problems of electrical interference but the babies were covered with a radiant heat shield (Hey and Mount, 1966), and their body temperatures did not fall.

\section{Results}

Twenty-six babies, all with very severe respiratory insufficiency, were investigated. 13 had virtually no EEG activity initially, even though they had normal blood gas tensions and normal blood pressures on the respirator. 7 of these 13 were of less than 25 weeks' gestation and $800 \mathrm{~g}$. birthweight, and showed the very low amplitude EEG activity which is seen at this gestation. They had blood pressures in the range $40 / 25-55 / 40 \mathrm{~mm}$. Hg, which we would also regard as normal at this maturity. The other 6 babies with inactive EEGs were also premature but of longer gestationbetween 28 and 34 weeks and of larger birthweightbetween $1200 \mathrm{~g}$. and $1900 \mathrm{~g}$. All 6 had suffered birth asphyxia. They were studied within the first 24 hours of life and had satisfactory blood gas tensions and systemic blood pressures. An inactive EEG in this situation is not incompatible with subsequent 
of Respirator Treatment and Outcome

\begin{tabular}{|c|c|c|c|c|c|c|}
\hline \multirow{2}{*}{$\frac{(\mathrm{mm} . \mathrm{Hg})}{\text { After }}$} & \multicolumn{2}{|c|}{$\begin{array}{l}\text { Blood Pressure } \\
(\mathrm{mm} . \mathrm{Hg})\end{array}$} & \multicolumn{2}{|c|}{$\begin{array}{l}\% \text { EEG Activity } \\
(>20 \mu \mathrm{V})\end{array}$} & \multirow{2}{*}{$\begin{array}{l}\text { Time Off } \\
\text { Respirator } \\
\text { (min.) }\end{array}$} & \multirow{2}{*}{ Outcome } \\
\hline & Before & After & Before & After & & \\
\hline 54 & $42 / 30$ & $36 / 26$ & 40 & 15 & 3 & $\begin{array}{l}\text { Died; necropsy: hyaline membrane disease; haemolytic } \\
\text { streptococcal septicaemia }\end{array}$ \\
\hline $\begin{array}{l}31 \\
36\end{array}$ & $\overline{66 / 38}$ & $\overline{66 / 30}$ & $\begin{array}{l}45 \\
80\end{array}$ & $\begin{array}{l}20 \\
15\end{array}$ & $\begin{array}{l}4 \\
5\end{array}$ & $\begin{array}{l}\text { Died; necropsy: airways obstruction; old IVH; throm- } \\
\text { bosed common iliac artery }\end{array}$ \\
\hline 43 & $42 / 30$ & $32 / 18$ & 50 & 30 & 5 & $\begin{array}{l}\text { Died; necropsy: hyaline membrane disease; thrombosed } \\
\text { common iliac artery }\end{array}$ \\
\hline 39 & $45 / ?$ & $45 / ?$ & 70 & 25 & 4 & Alive and well \\
\hline $\begin{array}{l}23 \\
36\end{array}$ & $\begin{array}{l}55 / 40 \\
50 / 30\end{array}$ & $\begin{array}{l}50 / 40 \\
42 / 30\end{array}$ & $\begin{array}{l}61 \\
60\end{array}$ & $\begin{array}{l}15 \\
40\end{array}$ & $\begin{array}{l}8 \\
4\end{array}$ & $\begin{array}{l}\text { Died; necropsy: airways obstruction; IVH; cerebral } \\
\text { venous thromboses }\end{array}$ \\
\hline $\begin{array}{l}33 \\
35\end{array}$ & $5 \overline{50 / ?}$ & $\overline{60 / ?}$ & $\begin{array}{l}53 \\
53\end{array}$ & $\begin{array}{l}25 \\
30\end{array}$ & $\begin{array}{l}6 \\
7\end{array}$ & $\begin{array}{l}\text { Died; weaned off respirator satisfactorily, but died } 5 \\
\text { weeks later from tracheal stenosis; necropsy: old IVH; } \\
\text { early hydrocephalus }\end{array}$ \\
\hline$\overline{-}$ & $\begin{array}{l}48 / 34 \\
50 / 35\end{array}$ & $\begin{array}{l}58 / 46 \\
60 / 40\end{array}$ & $\begin{array}{l}53 \\
25\end{array}$ & $\begin{array}{l}8 \\
8\end{array}$ & $\begin{array}{l}7 \\
4\end{array}$ & Died; necropsy: hyaline membrane disease; IVH \\
\hline $\begin{array}{l}34 \\
53\end{array}$ & $\begin{array}{l}52 / 35 \\
38 / 26\end{array}$ & $\begin{array}{l}60 / 40 \\
42 / 28\end{array}$ & $\begin{array}{l}51 \\
38\end{array}$ & $\begin{array}{r}17 \\
0\end{array}$ & $\begin{array}{l}3 \\
6\end{array}$ & $\begin{array}{l}\text { Died; necropsy: hyaline membrane disease; thrombosed } \\
\text { common iliac artery }\end{array}$ \\
\hline 24 & $40 / 30$ & $60 / 40$ & 38 & 0 & 6 & $\begin{array}{l}\text { Died; necropsy: hyaline membrane disease; IVH single } \\
\text { ventricle }\end{array}$ \\
\hline
\end{tabular}

survival, and one of this group did survive and is apparently neurologically normal.

Three babies when disconnected from the respirator maintained adequate ventilation and blood gas tensions and their EEG activity was $s$ stained as was their blood pressure. 2 of the 3 bavies subsequently had to be restarted on the ventilator and eventually died, but the other one survived. One other child, who was very hypotensive with a blood pressure of $30 / 20 \mathrm{~mm}$. $\mathrm{Hg}$, had a moderately inactive EEG which changed very little when the $\mathrm{P}_{\mathrm{a}} \mathrm{O}_{2}$ fell.

The remaining 9 babies had normal blood gas tensions and blood pressures with an active EEG while on the respirator. When they were disconnected from the respirator they were unable to maintain adequate gas exchange. Their arterial $\mathrm{Po}_{2}$ dropped and the EEG activity decreased. The remainder of this paper is concerned with these 9 babies, details of whom are shown in the Table.

In all, 14 attempts were made to wean these 9 babies off the respirator. All the babies had severe RDS judged on clinical grounds. Only one child survived. 5 of the 8 who died had intraventricular haemorrhages, and of the remaining 3 , 2 were in very poor condition on admission from outside units and had to be started on a ventilator immediately. The eighth fatality had an undiagnosed haemolytic streptococcal septicaemia. It can be seen that in all cases there was a drop in $\mathrm{P}_{\mathrm{a}} \mathrm{O}_{2}$ to levels less than $40 \mathrm{~mm} . \mathrm{Hg}$ and a fall in the percentage activity of the EEG, which in some cases became virtually flat. The longest time a baby was disconnected from the respirator was 8 minutes, and most babies had a significant decrease in activity within 4-5 minutes. The usual course of events was that from a normally active EEG (Fig. 1) there was marked slowing of the tracing (Fig. 2), followed by decrease in electrical activity (Fig. 3). In 8 out of the 14 attempts, the $\mathrm{P}_{\mathrm{a}} \mathrm{O}_{2}$ at the end of the attempt to wean the child off the respirator was less than $20 \mathrm{~mm}$. Hg. Fig. 4 shows that there is a significant correlation between the $\mathrm{P}_{\mathrm{a}} \mathrm{O}_{2}$ and the percentage activity of the EEG. We excluded from the analysis those recordings where the $\mathrm{P}_{\mathrm{a}} \mathrm{O}_{2}$ was more than $100 \mathrm{~mm}$. $\mathrm{Hg}$; $\mathrm{P}_{\mathrm{a}} \mathrm{O}_{2}$ values greater than normal are not likely to increase EEG activity.

Throughout the period of EEG slowing there was never any consistent change in the blood pressure. In some cases there was a fall of up to $10 \mathrm{~mm}$. Hg in the systolic pressure, but in others there was a rise of up to $20 \mathrm{~mm}$. $\mathrm{Hg}$. The $p \mathrm{H}$ and $\mathrm{P}_{\mathrm{a}} \mathrm{CO}_{2}$ values did not change significantly, and usually 

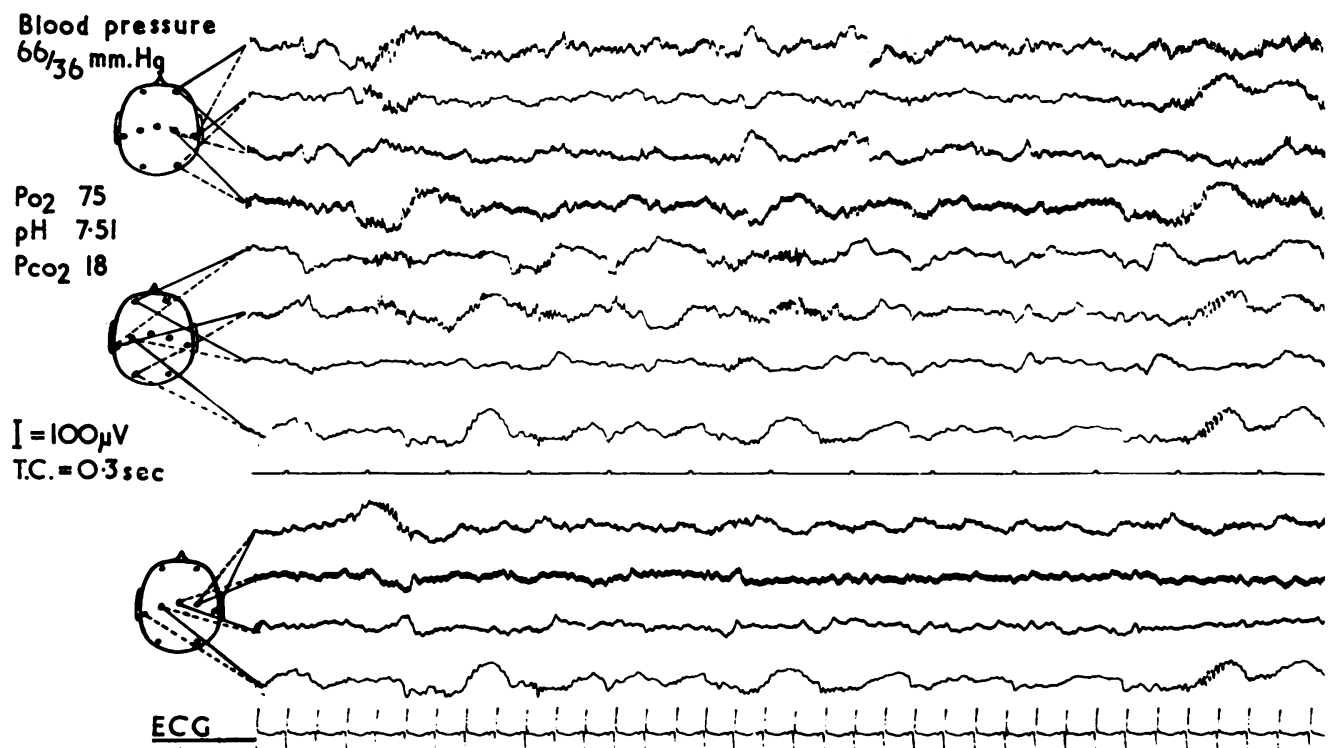

FIG. 1.-Case 2. Initial EEG tracing showing blood pressure and blood gas tensions before being disconnected from the respirator.

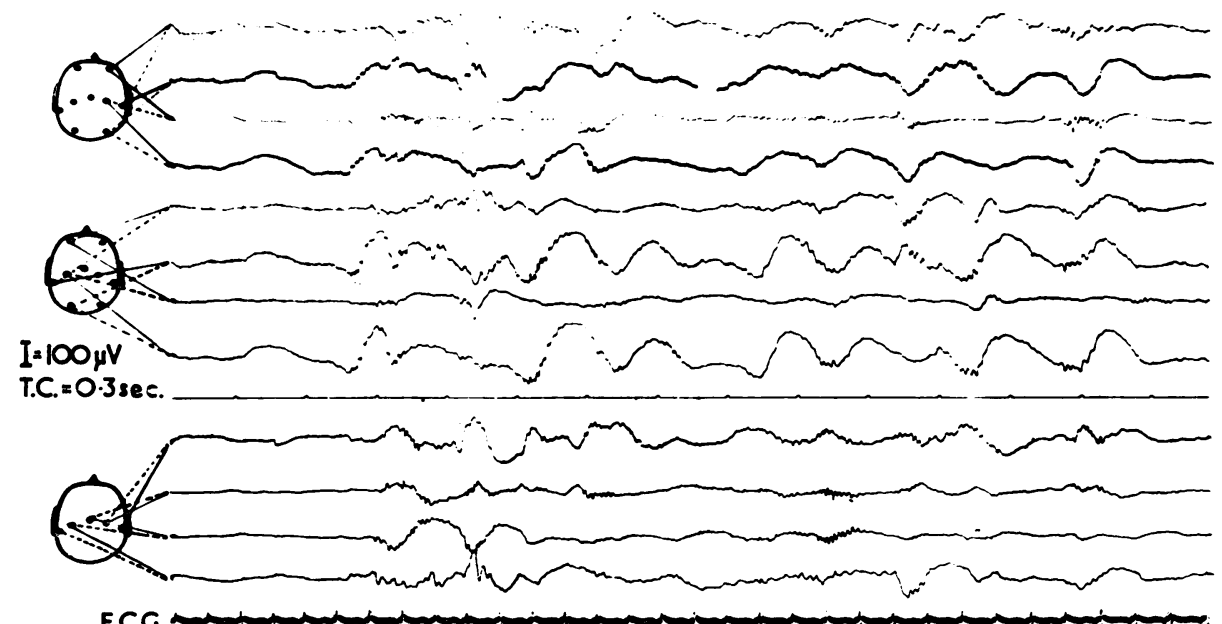

Fig. 2.-Case 6. EEG tracing during attempt to 'wean' the baby off the respirator.

remained within the normal range. If there was any significant change it was usually in the direction of correcting an abnormally high $p \mathrm{H}$ and correspondingly low $\mathrm{P}_{\mathrm{a}} \mathrm{CO}_{2}$ caused by overventilation, changes that are more likely to increase the cerebral blood flow and therefore maintain cerebral oxygenation and the EEG activity.

In all cases when the child was reconnected to the respirator the blood gas tensions and the EEG activity returned to normal within 10 minutes and usually within 3 minutes.

\section{Discussion}

The effect of hypoxia on the EEG of animals and adult human beings is well established, being an initial slowing of the activity progressing eventually to electrical silence (Gastaut et al., 1961). The levels of $\mathrm{Po}_{2}$ at which EEG flattening occurs are 


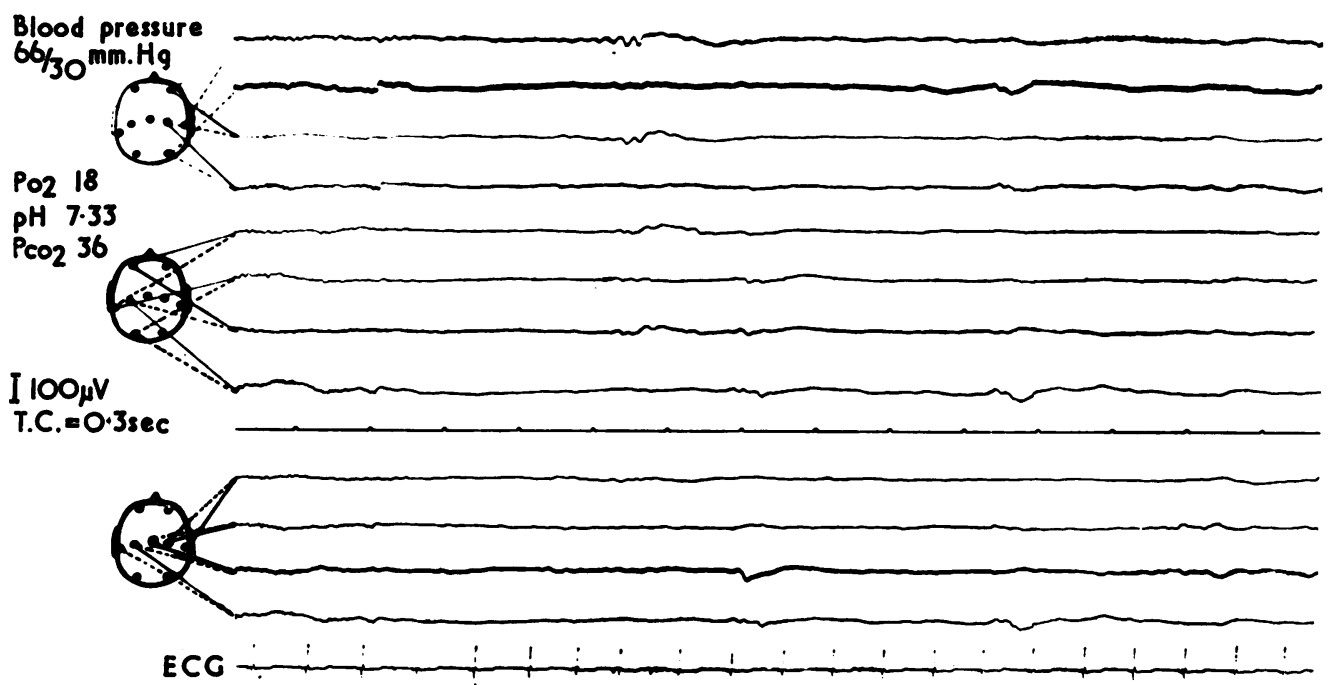

FIG. 3.-Case 2. Final EEG tracing showing blood pressure and blood gas tensions just before being reconnected to the respirator.

not well established. The most quoted figure in humans is that at a jugular venous $\mathrm{Po}_{2}$ of $20 \mathrm{~mm} . \mathrm{Hg}$ usually irrespective of the time taken to lower it to that level, slowing of the EEG takes place (Meyer, Gotoh, and Favale, 1965b; Meyer et al., 1965a; Meyer and Gotoh, 1964). There is, however, very little known on the arterial $\mathrm{Po}_{2}$ values associated with EEG changes, but Meyer et al. (1965a) found that EEG slowing took place at a $\mathrm{P}_{\mathrm{a}} \mathrm{O}_{2}$ of between 20 and $40 \mathrm{~mm}$. $\mathrm{Hg}$.

It is also known that in fetal rhesus monkeys approaching term the EEG is composed of low amplitude slow waves of $0 \cdot 5-1.5 \mathrm{cycle} / \mathrm{sec}$. dura-

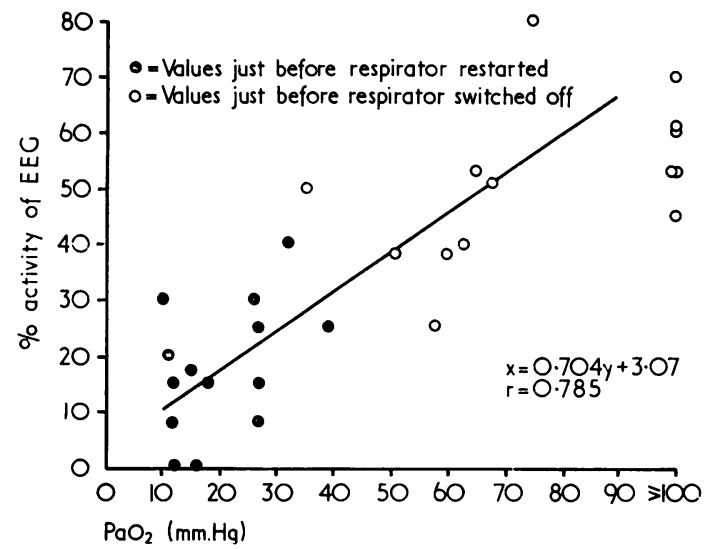

Fig. 4.-The relation between $P_{a} \mathrm{O}_{2}$ and percentage activity of the EEG. tion (Robert de Ramirez de Arellano, 1964). (In this species the umbilical arterial $\mathrm{Po}_{2}$ is $20 \mathrm{~mm}$. $\mathrm{Hg}$ (Dawes, 1968) and the carotid $\mathrm{P}_{\mathrm{a}} \mathrm{O}_{2}$ will presumably be slightly higher.) The activity and amplitude of the EEG rapidly increases after the newborn monkey takes its first gasp, and presumably coincides with the increasing arterial $\mathrm{Po}_{2}$.

The effect of lowering the blood pressure seems also to be largely a matter of hypoxia (Meyer et al., 1965b; Moyer and Morris, 1954; Brierly and Excell, 1966; Schneider, 1963). On lowering the blood pressure, slowing of the EEG and cerebral dysfunction (Moyer and Morris, 1954) only take place when the jugular venous $\mathrm{Po}_{2}$ drops below about $20 \mathrm{~mm}$. Hg. This follows a steadily increasing cerebral $\mathrm{AV} \mathrm{O}_{2}$ difference (Meyer et al., 1965a), which suggests that more oxygen is being extracted from the blood perfusing the brain at steadily decreasing blood pressure. Sudden onset of complete cerebral anoxia due to cessation of the cerebral circulation during cardiac surgery in infancy (Harden, Pampiglione, and Waterston, 1966; Thies-Puppel and Wiemers, 1961) or in Adams-Stokes attacks (Regis, Toga, and Righini, 1961) is associated with flattening of the EEG within one minute, and it is worth remembering that in heart surgery the EEG can be flat for at least 8 minutes, with complete recovery (ThiesPuppel and Wiemers, 1961).

Meyer et al. (1962) have shown in experiments on monkeys that cerebral tissue $\mathrm{Po}_{2}$ must be 
reduced from a normal of $26 \mathrm{~mm}$. $\mathrm{Hg}$ (mean) to $10 \mathrm{~mm}$. Hg before EEG slowing occurs and to even lower values for flattening.

The physiology of these EEG changes seems to be that when hypoxia occurs, cerebral metabolism decreases, as measured by a decreased jugular venous $\mathrm{PCO}_{2}$ (Meyer and Gotoh, 1964), the sodium pump in the nerve cells fails as evidenced by a low $\mathrm{Na}^{+}$and rising $\mathrm{K}+$ in jugular venous blood, and so neuronal repolarization cannot take place (Meyer et al., 1965a).

From our own studies it appears that the newborn baby's brain responds to hypoxaemia at least in terms of EEG activity in a similar way to the adult human and to the experimental animal, by showing an initial slowing of the activity followed by electrical silence. In one baby who was very hypotensive but adequately oxygenated, EEG activity was present; the 9 babies who showed EEG flattening had severe hypoxaemia but maintained their blood pressure; it seems likely, therefore, that, as in the adult, hypotension only causes EEG slowing when severe enough to cause cerebral hypoxia.

The $\mathrm{P}_{\mathrm{a}} \mathrm{O}_{2}$ level at which cerebral hypoxia takes place must obviously depend on the cerebral blood flow and the factors that influence it, such as blood pressure, $p \mathrm{H}$, and $\mathrm{P}_{\mathrm{a}} \mathrm{CO}_{2}$. The exact level of $\mathrm{P}_{\mathrm{a}} \mathrm{O}_{2}$ at which slowing and then flattening occurs could only be observed if a method for continuous $\mathrm{P}_{\mathrm{a}} \mathrm{O}_{2}$ recording such as an extracorporeal shunt were used. We have seen babies with severe RDS who have had normal EEGs at a $\mathrm{P}_{\mathrm{a}} \mathrm{O}_{2}$ of approximately $40 \mathrm{~mm}$. $\mathrm{Hg}$-indeed 1 of the 9 in this series started with a $\mathrm{P}_{\mathrm{a}} \mathrm{O}_{2}$ of $35 \mathrm{~mm} . \mathrm{Hg}$ and an active EEG, and we know that children with cyanotic congenital heart disease can be of normal intellect with arterial $\mathrm{Po}_{2}$ values in this range, though older children may show non-specific changes in their EEGs (Kohner et al., 1967).

However, at least one of our babies developed marked EEG flattening at a $\mathrm{P}_{\mathrm{a}} \mathrm{O}_{2}$ of $39 \mathrm{~mm}$. $\mathrm{Hg}$, and in several other babies one must assume that, as considerable slowing of the EEG had taken place some 1-2 minutes before the final $\mathrm{P}_{\mathrm{a}} \mathrm{O}_{2}$ reading shown in the Table, the $\mathrm{P}_{\mathrm{a}} \mathrm{O}_{2}$ was then higher and in the $35-40 \mathrm{~mm}$. $\mathrm{Hg}$ range. As levels of approximately $40 \mathrm{~mm}$. $\mathrm{Hg}$ can be associated with a normal EEG, and yet falls from high-normal values to the $40 \mathrm{~mm}$. $\mathrm{Hg}$ range are associated with EEG flattening, this suggests that sudden changes in $\mathrm{P}_{\mathrm{a}} \mathrm{O}_{2}$ may be more damaging than a gradual decline to a low level. This may explain McDonald's figures for severer CNS sequelae in children surviving cyanotic attacks than in other groups, and provides further reasons why apnoeic attacks are to be avoided. It appears reasonable, nevertheless, to suggest $40 \mathrm{~mm}$. $\mathrm{Hg}$ as the danger level below which the $\mathrm{P}_{\mathrm{a}} \mathrm{O}_{2}$ should not be allowed to fall.

The duration of EEG flattening inevitably associated with permanent cerebral damage is not known, but the brain of the newborn mammal is more resistant to hypoxaemia than that of older animals.

The fetal brain develops normally at abnormally low $\mathrm{P}_{\mathrm{a}} \mathrm{O}_{2}$ levels, and the work of Robert de Ramirez de Arellano (1964) suggests that low amplitude EEGs are normal in the fetus. However, it is not known what additional metabolic requirements of the brain become obligatory after birth. Until this is known it seems unwise to allow the EEG of the neonate to flatten or even to revert to the fetal pattern.

\section{Summary}

The EEG of the newborn baby responds to hypoxaemia in a similar way to that of an adult.

In periods of respiratory failure with hypoxaemia in the neonatal period the blood pressure is sustained as the EEG changes occur and $\mathrm{P}_{\mathrm{a}} \mathrm{O}_{2}$ falls. There is some evidence that acute changes in the $\mathrm{P}_{\mathrm{a}} \mathrm{O}_{2}$ are likely to be more damaging than gradual ones in terms of cerebral function.

I would like to thank Professor J. P. M. Tizard and Dr. R. J. Robinson for their help in the preparation of this paper; The Sir William Coxon Trust Fund and The British Epilepsy Association for providing assistance; Sister M. E. Castle and the Sisters of the neonatal ward and Misses U. Svendsen and J. Curtis who helped with some of the EEG tracings.

\section{REFERENCES}

Adams, J. H., Brierly, J. B., Connor, R. C. R., and Treip, C. S. (1966). The effects of systemic hypotension upon the human brain. Clinical and neuropathological observations in 11 cases. Brain, 89, 235.

Avery, M. E., and Oppenheimer, E. H. (1960). Recent increase in mortality from hyaline membrane disease. F. Pediat., 57, 553.

Brierly, J. B., and Excell, B. J. (1966). The effects of profound systemic hypotension upon the brain of $M$. rhesus. Physiological and pathological observations. Brain, 89, 269.

Cahn, J., Mathis, P., Herold, M., Alano, J., van Holten, I., and Barré, N. (1961). Effects of acute anoxia on EEG and brain metabolism in the rabbit and dog. In Cerebral Anoxia and the EEG, p. 89 . Ed. by H. Gastaut and J. S. Meyer. Thomas, Springfield, Illinois.

Dawes, G. S. (1968). Fetal and Neonatal Physiology, p. 111. Year Book Medical Publishers, Chicago.

Dreyfus-Brisac, C. (1964). The electroencephalogram of the premature infant, and full-term newborn; normal and abnormal development of waking and sleeping patterns. In Neurological and Encephalographic Correlative Studies in Infancy, p. 186. Ed. by P. Kellaway and I. Petersen. Grune and Stratton, New York.

Gastaut, H., Fischgold, H., and Meyer, J. S. (1961). Conclusions of the International Colloquium on Anoxia and the EEG. In Cerebral Anoxia and the EEG, p. 599 . Ed. by H. Gastaut and J. S. Meyer. Thomas, Springfield, Illinois. 
Goldie, L., and Van Velzer, C. (1965). Innate sleep rhythms. Brain, 88, 1043.

Grausz, J. P., Watt, N. L., and Becket, A. J. (1967). A new positive-pressure respirator for newborns. Lancet, $2,499$.

Harden, A., Pampiglione, G., and Waterston, D. J. (1966). Circulatory arrest during hypothermia in cardiac surgery: an EEG study in children. Brit. med. F., 2, 1105.

Hey, E., and Mount, L. (1966). Temperature control in incubators. Lancet, 2, 202.

Kohner, E. M., Allen, E. M., Saunders, K. B., Emery, V. M., and Pallis, C. (1967). Electroencephalogram and retinal vessels in congenital cyanotic heart disease before and after surgery. Brit. med. F., 4, 207.

McDonald, A. D. (1963). Cerebral palsy in children of very low birth weight. Arch. Dis. Childh., 38, 579.

- (1967). Children of Very Low Birth Weight (M.E.I.U. Research Monograph No. I). Spastics Society and William Heinemann, London.

Meyer, J. S., and Gotoh, F. (1964). Continuous recording of cerebral metabolism, internal jugular flow and EEG in man. Trans. Amer. neurol. Ass., 89, 151.

- - - Ebihara, S., and Tomita, M. (1965a). Effects of anoxia on cerebral metabolism and electrolytes in man. Neurology (Minneap.), 15, 892.

- - - , and Favale, E. (1965b). Effects of carotid compression on cerebral metabolism and electroencephalogram. Electroenceph. clin. Neurophysiol., 19, 362.

_, - Tazaki, Y., Hamaguchi, K., Ishikawa, S., Nouailhat, F., and Symon, L. (1962). Regional cerebral blood flow and metabolism in vivo. Arch. Neurol. (Chic.), 7, 560.

Moyer, J. H., and Morris, G. (1954). Cerebral hemodynamics during controlled hypotension induced by the continuous infusion of ganglion blocking agents. $\mathcal{F}$. clin. Invest., 33, 1081

Neligan, G. A., and Smith, C. A. (1960). The blood pressure of newborn infants in asphyxial states and in hyaline membrane disease. Pediatrics, 26, 735.
Northway, W. H., Jr., Rosan, R. C., and Porter, D. Y. (1967). Pulmonary disease following respirator therapy of hyalinemembrane disease. New Engl. F. Med., 276, 357.

Regis, H., Toga, M., and Righini, C. (1961). Clinical, electroencephalographic and pathological study of a case of AdamsStokes syndrome. In Cerebral Anoxia and the EEG, p. 295. Ed. by H. Gastaut and J. S. Meyer. Thomas, Springfield, Illinois.

Robert de Ramirez de Arellano, M. I. (1964). Electroencephalogram of the monkey fetus in utero, and changes in it at birth. In Neurological and Electroencephalographic Correlative Studies in Infancy, p. 158. Ed. by P. Kellaway, and I. Petersen. Grune and Stratton, New York.

Roberton, N. R. C., Gupta, J. M., Dahlenburg, G. W., and Tizard, J. P. M. (1968). Oxygen therapy in the newborn. Lancet, 1 , 1323.

Robinson, R. (1966). Cerebral function in the newborn. Develop. Med. Child Neurol.. 8, 561 .

Schneider, M. (1963). Critical blood pressure in the cerebral circulation. In Selective Vulnerability of the Brain to Hypoxaemia, p. 7. Ed. by J. P. Schadé and W. H. McMenemey. Oxford University Press, London.

Thies-Puppel, H., and Wiemers, K. (1961). Survival time and latency of recovery of EEG during heart surgery in hypothermia. Cerebral Anoxia and the EEG, p. 279 . Ed. by H. Gastaut and J. S. Meyer. Thomas, Springfield, Illinois.

Correspondence to Dr. N. R. C. Roberton, 57 Kelburne Road, Cowley, Oxford.

Reprint requests to Hammersmith Hospital, London W.12. 